\title{
CONCRETE PROPERTIES EVALUATED BY REPLACING CEMENT WITH ALCCOFINE
}

\author{
BLN Sai Srinath $1 \square$ (iD), Chandan Kumar Patnaikuni $2 \square$ (iD
}

${ }^{1} \mathrm{Ph}$. D Research Scholar, Civil Engineering Department, GITAM Institute of Technology, Visakhapatnam 530045, Andhra Pradesh, India

${ }^{2}$ Assistant Professor, Civil Engineering Department, GITAM Institute of Technology, Visakhapatnam 530045, Andhra Pradesh, India

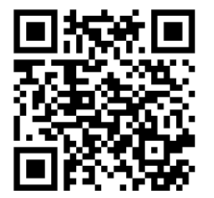

Received 15 December 2022

Accepted 1 January 2022

Published 18 February 2022

CorrespondingAuthor

BLN Sai Srinath,

srinath296@gmail.com

DOI 10.29121/IJOEST.v6.i1.2022.279

Funding: This research received no specific grant from any funding agency in the public, commercial, or not-for-profit sectors.

Copyright: (C) 2022 The Author(s). This is an open access article distributed under the terms of the Creative Commons Attribution License, which permits unrestricted use, distribution, and reproduction in any medium, provided the original author and source are credited.

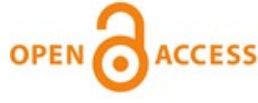

\section{ABSTRACT}

Nowadays, many research works are being conducted throughout the world to develop cementitious materials that can replace cement. As a replacement for cement in concrete, fly ash, silica fume, GGBS, Metakaolin, Micro materials, Quartz powder, etc. are tried out in that order. This experiment tries out a new ultrafine material called Alccofine for a partial replacement. This concrete grade, M40, was developed for testing the cementing efficiency of Alccofine with a variety of percentages of replacement of cement with Alccofine, such as 5\%,10\%,15\%, and 20\%. A design mix has been developed for M40 grade and cubes have been cast with varying percentages of alccofine, as described above. A discussion of the results has been provided. Compared to other mix percentages, $15 \%$ of alccofine replacement with cement produces good strength. The SEM images shows that Alccofine is found to have good cementing efficiency in earlier ages of concrete.

Keywords: Cementing Efficiency, Alccofine, SCM

\section{INTRODUCTION}

The whole world is moving towards globalization in infrastructure development. India is an important part of the world where globalization in every field plays a very important role. The infrastructure development of any country depends upon concrete. Concrete is one of the most commonly used construction materials in the construction industry and it is a basic civil engineering construction material used all over the world because of its structural stability, strength and high molding ability. The workability should be good for getting the desired shape on the site. As compared to steel/wooden structures, the concrete structure has a low maintenance cost. Due to the increase in the population, there is a change in living standards. The demand for infrastructure development, therefore concrete becomes a major part of the construction. Conventional concrete does not meet the present day's demands of construction hence developing new construction materials [i.e., improved properties]. For knowing the concrete quality, the compressive strength of concrete is required for 28 days of proper curing. The concrete structure may fail before their service period because of very lack of durability of the concrete. The low $\mathrm{w} / \mathrm{c}$ ratio reduces the permeability of hardened concrete. The addition of cementitious materials to the concrete as replaced partially also improves the durability of the concrete. 
The Alccofine 1203 product is a specially processed slag containing a high percentage of glass, resulting from a controlled granulation process. An enhanced hydration process is a result of both the latent hydraulic property and pozzolanic reactivity. With the addition of Alccofine, the paste component will pack more densely. Therefore, concrete at any age will be stronger and more durable due to a reduction in water demand.
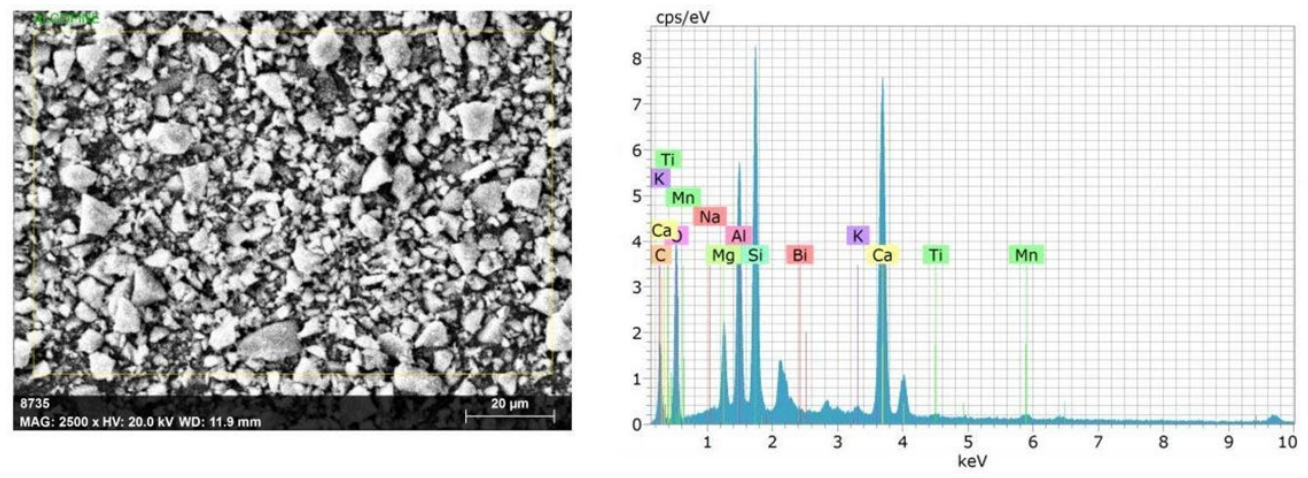

Figure 1 SEM image and chemical composition of Cement
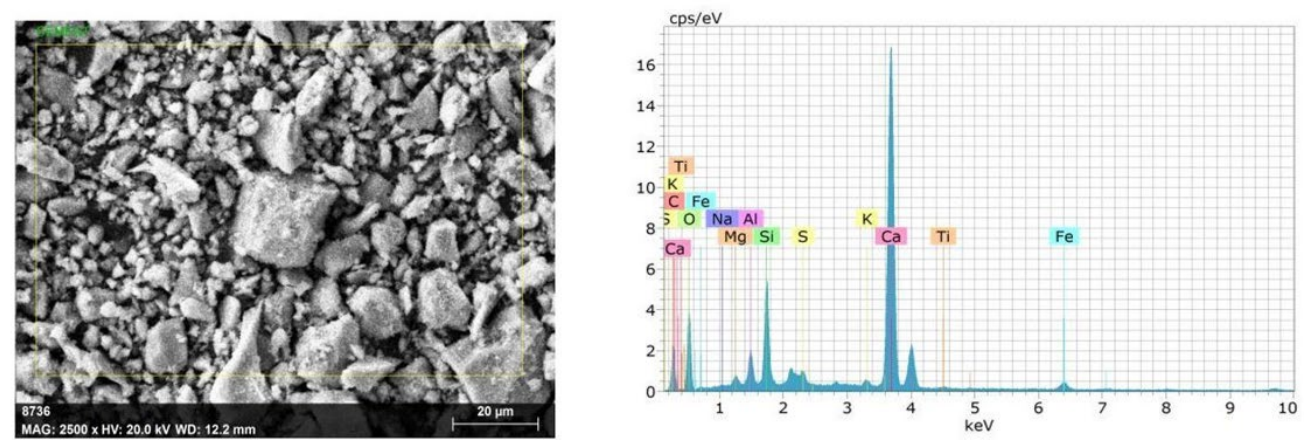

Figure 2 SEM image and chemical composition of Alccofine

Mix design was performed in accordance with IS 10262: 2019 code for trail mix for M40 grade. Alccofine was used as a substitute for cement at percentages of 0 , $5 \%, 10 \%, 15 \%$, and $20 \%$ for concrete of grade M40. In addition to cement and fine aggregate, coarse aggregate and water were also used in the mix design. Moreover, Alccofine 1203 increases concrete's strength, thereby providing the concrete with more workability and other advantages.

\subsection{CEMENT}

used for all specimens was ordinary Portland cement of 53 grade confirming to IS: 12269:2013 was used. The cement used for all specimens was ordinary Portland cement grade 53 that complied with IS: 12269:2013.

\subsection{ALCCOFINE 1203}

In comparison to its chemical composition and physical characteristics listed below, ALCCOFINE 1203 has a unique chemical composition primarily composed of $\mathrm{CaO} 30-34 \%$ and $\mathrm{SiO}_{2} 30-36 \%$. In terms of particle size distribution, the product is physically unique. 

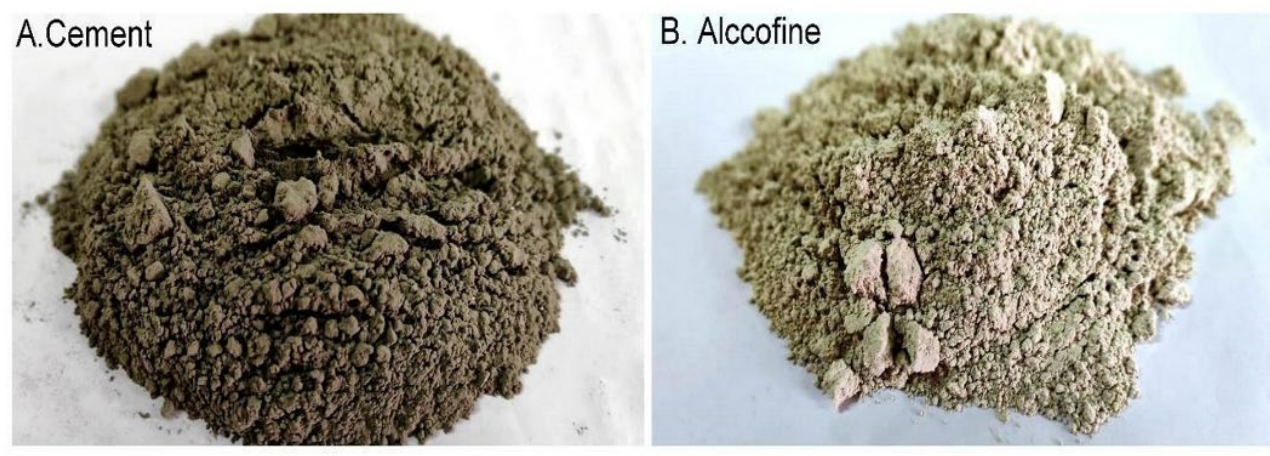

Figure 3 Cement and Alccofine

\begin{tabular}{|c|c|c|c|c|}
\hline $\begin{array}{c}\text { Compounds and } \\
\text { elements }\end{array}$ & $\begin{array}{l}\text { Compound } \\
\text { formula }\end{array}$ & $\begin{array}{c}\text { Cement } \\
(\%)\end{array}$ & $\begin{array}{c}\text { Alccofine } \\
(\%)\end{array}$ & $\begin{array}{c}\text { Composition of cement as } \\
\text { per IS } 12269-2013(\%)\end{array}$ \\
\hline Calcium & $\mathrm{CaO}$ & 72.82 & 39.17 & $60-67$ \\
\hline Silicon & $\mathrm{SiO}_{2}$ & 14.64 & 29.22 & $17-25$ \\
\hline Iron & $\mathrm{FeO}$ & 3.62 & - & $0.5-6$ \\
\hline Aluminium & $\mathrm{Al}_{2} \mathrm{O}_{3}$ & 4.78 & 20.19 & 03-Aug \\
\hline Sulphur & $\mathrm{SO}_{3}$ & 2.32 & - & 01-Mar \\
\hline Magnesium & $\mathrm{MgO}$ & 1.14 & 6.62 & $0.1-4$ \\
\hline Potassium & $\mathrm{K}_{2} \mathrm{O}$ & 0.4 & 0.25 & $0.1-1$ \\
\hline Sodium & $\mathrm{Na}_{2} \mathrm{O}$ & 0.22 & 0.06 & $0.1-1$ \\
\hline Titanium & $\mathrm{TiO}_{2}$ & 0.07 & 0.24 & - \\
\hline
\end{tabular}

\subsection{FINE AGGREGATE}

The fine aggregate is as per the IS 383-1970 code conforming that is coming under ZONE II. The fine aggregate is in accordance with the IS 383-1970 code, which falls under Zone II.

The coarse aggregate conforming to IS 383-1970 was used. In this project, coarse aggregates that conform to IS: 383-1970 were used. Aggregates ranging in size from 12 to $20 \mathrm{~mm}$ were used.
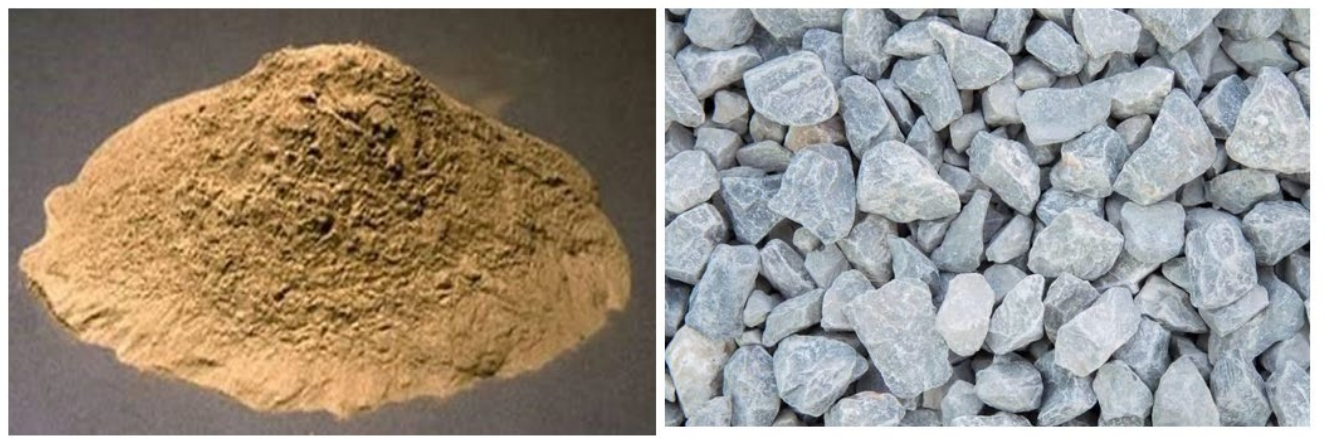

Figure 4 Fine and coarse aggregates used in experimentation 
Table 2 Mix proportions of M40 grade concrete /cum

\begin{tabular}{cccccc}
\hline & $\mathbf{0 \%}$ & $\mathbf{5 \%}$ & $\mathbf{1 0 \%}$ & $\mathbf{1 5 \%}$ & $\mathbf{2 0 \%}$ \\
\hline Cement & 367 & 399 & 378 & 357 & 336 \\
\hline AL & 0 & 21 & 42 & 63 & 84 \\
\hline Water & 148 & 152 & 152 & 152 & 152 \\
\hline F.A. & 767 & 646.6 & 646.6 & 616 & 646.6 \\
\hline C.A. & 1140 & 1322 & 1322 & 1308 & 1322 \\
\hline SP & 3.7 & 4.2 & 34.2 & 4.2 & 3.4 .2 \\
\hline
\end{tabular}

\subsection{WATER}

Potable water was used to mix concrete and cure specimens.

\subsection{CONCRETE}

The cement used is Portland Cement 53 grade. Tests are conducted on cement based on the procedures prescribed in IS: 1489. Maximum size of $20 \mathrm{~mm}$ for aggregate and a size range of 0 to $4.75 \mathrm{~mm}$ for fine aggregate is required. In order for the concrete to stabilize its own properties, such as compressive strength, it needs to be allowed to cure in real environmental conditions for about 28 days. A concrete cube $(100 \mathrm{~mm} \times 100 \mathrm{~mm} \times 100 \mathrm{~mm})$ is loaded under axial compression to test its strength.

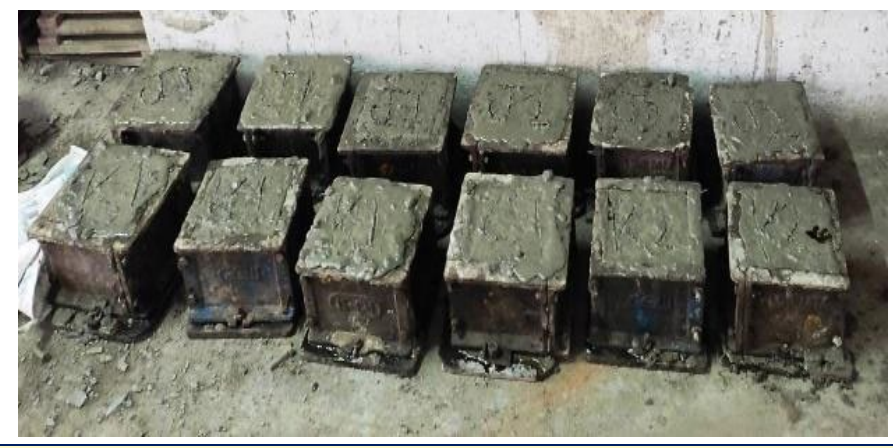

Figure 5 Casting of concrete cubes

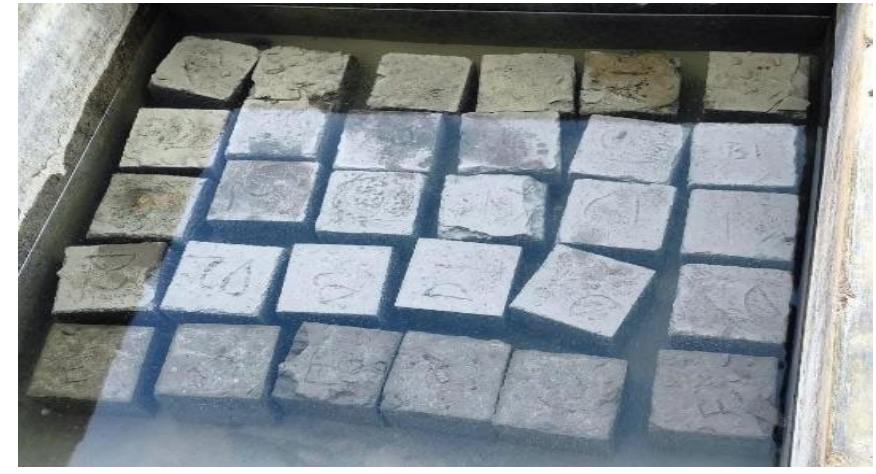

Figure 6 Cubes allowed for curing in curing tanks

\subsection{COMPRESSIVE STRENGTH}

A material's capacity to withstand pressure that tends to reduce its size is its compressive strength 


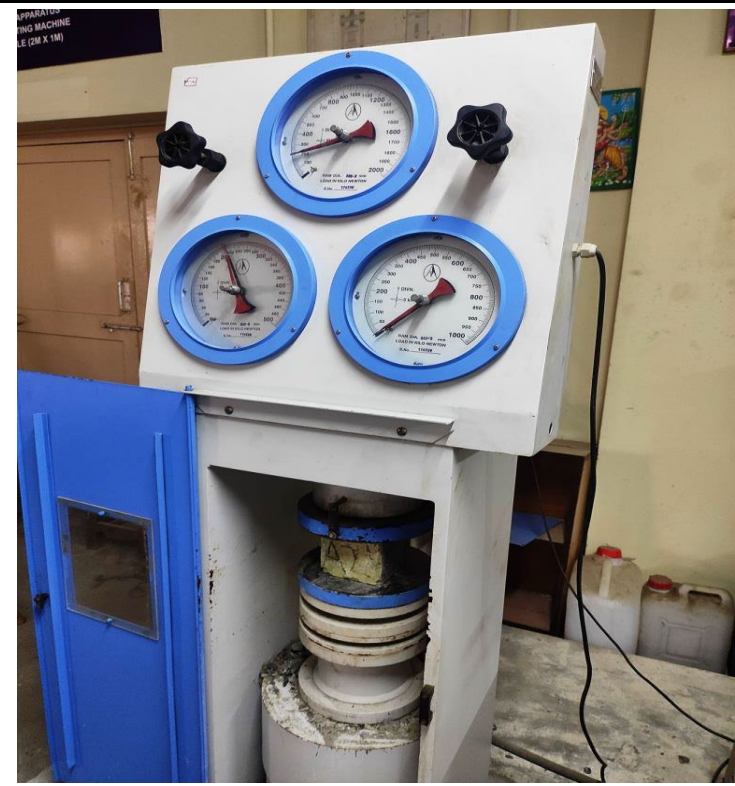

Figure 7 Compression testing machine (C.T.M.)

\section{RESULTS AND DISCUSSION}

In this study, the compressive strength of concrete mixed at various proportions will be determined. Graphs and bar charts are used to present the test results. Figure 5 shows various mix proportions of concrete and the results obtained in terms of compressive strength.

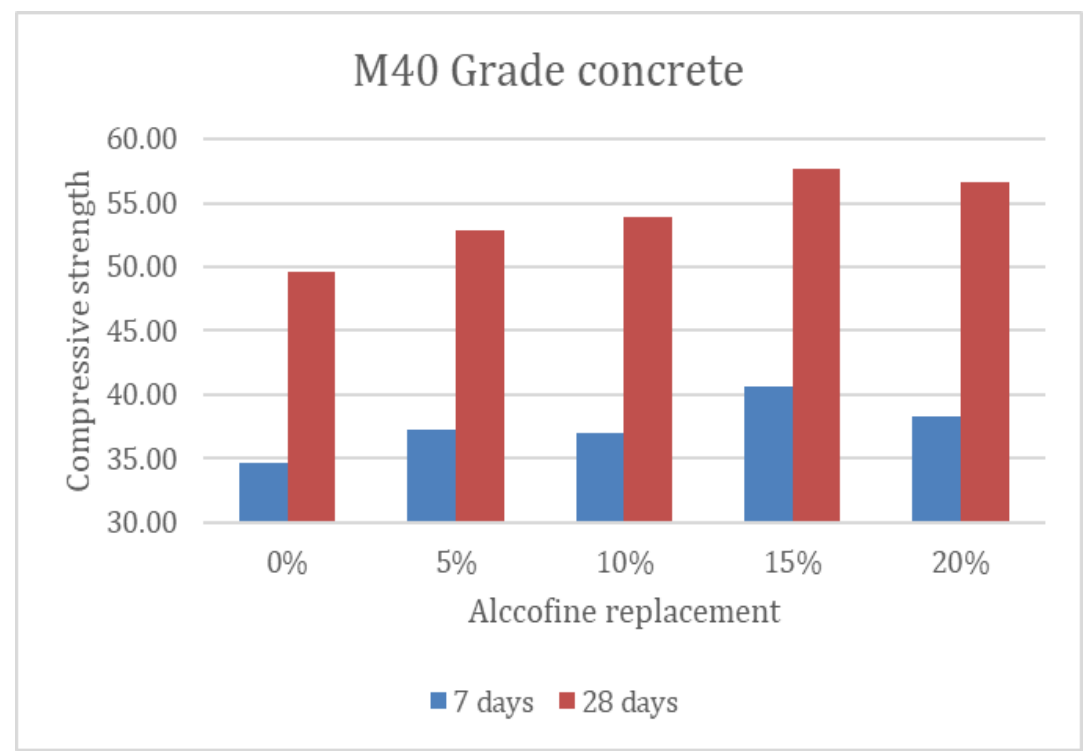

Figure 8 Compressive Strength for M40 Grade Mix

Figure 7 and Figure 8 illustrate the compressive strength values of Alccofine dosages in concrete after 7 and 28 days of curing. With increasing curing durations and extended hydration periods, the compressive strength improves with age. In the initial mixes containing only Alccofine, the maximum strength was observed for $15 \%$. 

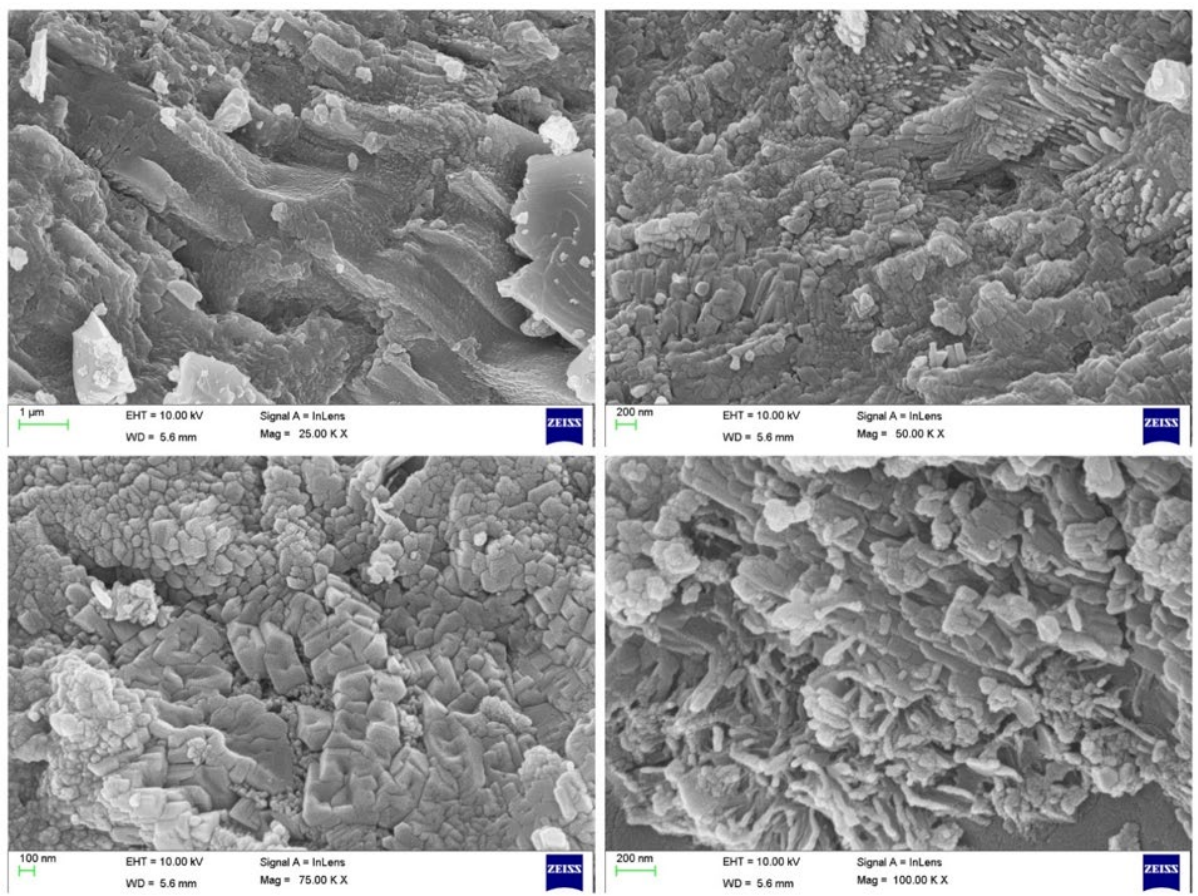

Figure 9 Microscopic images of M40 grade concrete at 15\% optimum dosage of Alccofine

For M40 grade concrete with $15 \%$, Alccofine replacement, it exhibited a maximum compressive strength of $40.62 \mathrm{mpa}$ and $57.65 \mathrm{mpa}$ after 7 days and 28 days respectively.

For this mix, from 7 days to 28 days, there was an increase of $29.54 \%$. At 7 days and 28 days, the compressive strength gain compared to the conventional mix is $17.06 \%$ and $16.23 \%$ respectively. At 7 days, the compressive strength of $10 \%$ mix and $20 \%$ mix is lower than that of $15 \%$ mix, by $10.08 \%$ and $6.34 \%$ respectively. At 28 days, the compressive strength of $10 \%$ mix and $20 \%$ mix is lower than that of $15 \%$ mix, by $7.16 \%$ and $1.68 \%$ respectively. Therefore, it is observed that the $15 \%$ mix shows higher strength than all other mixes.

\section{CONCLUSIONS}

According to the experimental results, the following conclusions can be drawn:

- Compared to other mixes (0\%, 5\%,10\% and 20\%), 15\% replacement mix gives better compressive strength. Concrete's compressive strength increases when alccofine is added.

- Increasing the level of alccofine above $15 \%$ in a mix will only act as a filler material, while its strength will gradually decrease over time.

- The test results indicate that weight loss decreases as alccofine addition increases. However, there is a limitation that strength will decrease with increased alccofine concentration.

- We conclude that alccofine 1203 was a good cementitious material replacement to the extent of $15 \%$. Furthermore, its durability is also excellent.

- Furthermore, further research is needed to standardize the use of alccofine in concrete.

- The concrete shows denser and homogeneous microstructure for concrete containing 15\% alccofine. Due to presence of silica and calcium 
in Alccofine, there was extra formation of CSH gel which is clearly shown in the microstructure.

\section{REFERENCES}

A.C. Saoji and M.S. Pawar (2013) Effect of Alccofine on Self Compacting Concrete. The international journal of engineering and science, Vol.2, 5-9.

Abhijisinh (2009) "Utilization of pond fly ash as à partial replacement in fine aggregate with using fine fly ash and Alccofine in HSC- Hards concrete properties". International Journal of Engineering Development and Research, Vol.4, 74-77.

Ali Bashah (2006). Effect of silica fume to the strength and permeability of highperformance ground granulated blast furnace slag concrete. University Technology Malaysia, pp.1-68.

Aponte F, M Barra, and Vazquez (2012) Durability and cementing efficiency of fly ash in concretes. Construction and Building Material, Vol.30, 537-546. Retrieved from https://doi.org/10.1016/j.conbuildmat.2011.12.026

B.K. Shah and Suthar Sunil (2013). Strength development of high strength concrete containing Alccofine and fly-ash. Indian journal of research, Vol.2, 102-104. Retrieved from https://doi.org/10.15373/22501991/MAR2013/38

Bureau of Indian Standards, IS : 456 - 2000 Code of practice for Plain and Reinforced Concrete (third edition) New Delhi, India.

Bureau of Indian Standards, IS : 10262-2009 Concrete mix proportioning (First revision), New Delhi, India.

Bureau of Indian Standards, IS : 12269 - 2013 Specification for 53 grades ordinary Portland cement (first revision) New Delhi, India.

Bureau of Indian Standards, IS : 383 - 1970 Specification for fine and coarse aggregates from natural sources of concrete (Second revision) Jan 2007. New Delhi, India.

Bureau of Indian Standards, IS : 516 - 1959 Methods of tests for strength of concrete.New Delhi, India.

Darren Lim, Sabet Divsholi, Da Xu, Susanto Teng, Kondraivendhan (2011). Effect of ultrafine slag replacement on durability and mechanical properties of high strength concrete. 36th Conference of Our World in Concrete \& Structures, Nanyang Technological University, 14-16.

Dr. Mohd.Hamraj (2014) Experimental Study On Binary blended high strength steel fiber reinforced concrete using Alccofine as mineral admixture, International journal of science and technology, Vol.2, 56-62.

F.Gameiro, J.de Brito and D.Correia da silva (2014) Durability performance of structural concrete containing fine aggregates from waste generated by the marble quarrying industry. Engineering Structures, Vol.59, 654-662. Retrieved from https://doi.org/10.1016/j.engstruct.2013.11.026

M.A. Jamnu, Siddharth P Upadhyay, (2014) Effect on compressive strength of highperformance concrete incorporating Alccofine and fly ash. Journal On International Academic Research For Multidisciplinary, Vol.2 125-130.

Saud Otaibi (2004) Durability related properties of alkali-activated slag concrete. 29th Conference of our world in concrete \& structures, Kuwait Institute for Scientific Research, Singapore : 25 -26 August.

Swaroop, Venkateswara K and Kodandarama Rao (2013). Durability studies on concrete with fly ash and GGBS, International Journal Of Engineering Research and Applications, Vol.3, pp 285-289. 